Our Nature 2013, 11(2): 187-191

\title{
Pre-harvest Weeds of a Wheat Field at Biratnagar, Nepal
}

\author{
Bhabindra Niroula \\ Department of Botany, Post Graduate Campus, T.U., Biratnagar, Nepal \\ E-mail:niroulab@gmail.com
}

Received: 26.11.2013; Accepted: 24.12.2013

\begin{abstract}
Sixty eight species of weeds belonging to 22 families and 59 genera were recorded from a wheat field at Biratnagar during the pre-harvest condition. Based on species prevalence the dominant weed families were Asteraceae (17 species), Poaceae (13 species) and Fabaceae (6 species). Anagallis arvensis, Crepis japonica, Grangea maderaspatana, Polygonum plebeium were abundant and Fumaria indica, Leucas lavandulifilia, Rumex dentatus, Vicia angustifolia, V. hirsuta and V. tetrasperma were common species of weeds.
\end{abstract}

Key words: Weed flora, dicots, monocots, asteraceae, Anagallis arvensis, phenophase

\section{Introduction}

Weed interference is a major production constraint in agriculture (Rajbhandari and Joshi, 1998). A survey of the major weeds and their composition in cultivated fields of a particular crop and agro-climatic zone is essential. Wheat (Triticum aestivum L., Poaceae) is an important cereal crop of Nepal. Economic weed management measures of wheat field require information on weed species associated with the crop. In view of evolving a sustainable weed control strategy knowledge of their ecology and biology is highly desirable (Bhowmik, 2000).

Weed flora of wheat field in Nepal have been studied by Chaudhary (1979), Devkota (1983), Ranjit (1983), Rajbhandari and Joshi (1998), Rajbhandary and Ojha (1998) and Dangol (2000-2002). Present study aims to communicate the species composition, abundance and phenophase of weeds occurring in a wheat field at Biratnagar.
The study area (35 ha) is located in Biratnagar sub-metropolitan city (Lat $26^{\circ} 22^{\prime} \mathrm{N}$ Long $87^{\circ} 16^{\prime} \mathrm{E}$, Alt. $72 \mathrm{msl}$ ) in eastern Terai plain of Nepal. The climate of Biratnagar is tropical and monsoon. There are three distinct seasons viz. summer (March-June), rainy (July-October) and winter (November-February). Soil is alluvial and loamy in texture (sand $40 \%$, silt $40 \%$ and clay $20 \%$ ). The average $\mathrm{pH}$ of the soil $(0-10 \mathrm{~cm}$ depth) is 6.5 . The farmland is characterized by periodic cultivation of annual crops, paddy and wheat by rotation. It remains fallow for two months in both winter and summer seasons after harvesting. The land is subjected to grazing during the post harvest durations.

\section{Materials and methods}

The study was carried out in March 2013, two weeks before the harvest of wheat. Weeds were identified using standard literature (Hooker, 1872-1897). Nomencl- 
Table 1. Occurrence and phenophase of weeds in pre-harvest wheat field.

\begin{tabular}{|c|c|c|c|c|}
\hline$\overline{\mathbf{S N}}$ & 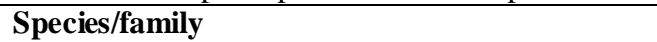 & Local name & Phenophase & Occur. \\
\hline & $\begin{array}{l}\text { Dicotyledonae } \\
\text { Acanthaceae }\end{array}$ & & & \\
\hline 1. & Hemigraphis hirta (Vahl) T. Ander & - & Veg & ++ \\
\hline 2. & $\begin{array}{l}\text { Rungia pectinata (L.) Nees } \\
\text { Amaranthaceae }\end{array}$ & - & $\mathrm{Fl}$ & ++ \\
\hline 3. & Alternanthera paronychioides St.-Hill & - & Veg & + \\
\hline 4. & A. philoxeroides (Mart.) Griseb. & Jaljamboo & Veg & ++ \\
\hline 5. & A. sessilis (L.) R. Br. & Bhiringi jhaar & $\mathrm{Fl}$ & +++ \\
\hline 6. & $\begin{array}{l}\text { Amaranthus viridis } \mathrm{L} \text {. } \\
\text { Apiaceae }\end{array}$ & Lunde & $\mathrm{Fl}$ & ++ \\
\hline 7. & Centella asiatica (L.) Urb. & Ghodtapre & Veg & ++ \\
\hline 8. & $\begin{array}{l}\text { Hydrocotyle sibthorpioides Lam. } \\
\text { Asteraceae }\end{array}$ & Ghodtapre & Veg & ++ \\
\hline 9. & Ageratum haustonianum Mill. & Ilame jhaar & $\mathrm{Fl}$ & ++ \\
\hline 10. & Bidens sp. & Kuro & Veg & + \\
\hline 11. & Blumea mollis (D. Don) Merr & Gande jhaar & $\mathrm{Fl}$ & ++ \\
\hline 12. & Breea arvensis (L.) Less. & Gaidakande & $\mathrm{Fl}$ & ++ \\
\hline 13. & Centipeda minima (L.) A. Br. and Asch & Hachhiu jhaar & $\mathrm{Fl}$ & ++ \\
\hline 14. & Cotula hemispherica (Roxb.) Wall. ex C.B. Clarke & - & $\mathrm{Fl}$ & ++ \\
\hline 15. & Crepis japonica (L.) Benth. & - & Fr & +++ \\
\hline 16. & Eclipta prostrata (L.) L. & Bhringaraj & Fr & ++ \\
\hline 17. & Gnaphalium polycaulon Pers & Buki jhaar & $\mathrm{Fr}$ & +++ \\
\hline 18. & Grangea maderaspatana (L.) Poir & Gobre jhaar & Fr & ++++ \\
\hline 19. & Ixeris polycephala Cass. & Dudhe jhaar & $\mathrm{Fl}$ & ++ \\
\hline 20. & Parthenium hysterophorus $\mathrm{L}$. & Congress jhaar & $\mathrm{Fl}$ & ++ \\
\hline 21. & Senecio sp. Wall & - & $\mathrm{Fl}$ & + \\
\hline 22. & Senecio vulgaris $\mathrm{L}$. & - & Veg & ++ \\
\hline 23. & Sphaeranthus indicus $\mathrm{L}$. & Purpure jhaar & $\mathrm{Fl}$ & ++ \\
\hline 24. & Spilanthes iabadicensis A. H. Moore & Purpure jhaar & Veg & ++ \\
\hline 25. & $\begin{array}{l}\text { Xanthium strumarium } \mathrm{L} \\
\text { Boraginaceae }\end{array}$ & Bhende kuro & $\mathrm{Fl}$ & ++ \\
\hline 26. & $\begin{array}{l}\text { Heliotropium strigosum Wild } \\
\text { Chenopodiaceae }\end{array}$ & Hatisunde & Veg & ++ \\
\hline 27. & Chenopodium album $\mathrm{L}$ & Bethe & Veg & ++ \\
\hline 28. & $\begin{array}{l}\text { C. ambrosioides } \mathrm{L} \text {. } \\
\text { Euphorbiaceae }\end{array}$ & Gande jhaar & Veg & ++ \\
\hline 29. & $\begin{array}{l}\text { Croton bonplandianum Baill. } \\
\text { Fabaceae }\end{array}$ & Khursane jhaar & Veg & +++ \\
\hline 30. & Cassia tora $\mathrm{L}$. & Tapre & $\mathrm{Fl}$ & + \\
\hline 31. & C. occidentalis $\mathrm{L}$. & Tapre & Veg & + \\
\hline 32. & Lathyrus aphaca $\mathrm{L}$. & Bankerau & $\mathrm{Fr}$ & ++ \\
\hline 33. & Vicia angustifolia $\mathrm{L}$. & Narkat & $\mathrm{Fr}$ & +++ \\
\hline 34. & V. hirsuta (L.) S. F. Gray & Kutuli kosa & Fr & +++ \\
\hline 35. & $\begin{array}{l}\text { V. tetrasperma }(\mathrm{L} .) \text { Moench } \\
\text { Fumariaceae }\end{array}$ & Kutuli kosa & $\mathrm{Fr}$ & ++ \\
\hline 36. & $\begin{array}{l}\text { Fumaria indica Pugsley } \\
\text { Lamiaceae }\end{array}$ & Banganjar & $\mathrm{Fr}$ & +++ \\
\hline 37. & Leucas lavandulifilia Smith & Drona puspi & Veg & +++ \\
\hline 38. & $\begin{array}{l}\text { Salvia plebeia } \mathrm{R} . \mathrm{Br} \text {. } \\
\text { Meliaceae }\end{array}$ & Bantulsi & $\mathrm{Fr}$ & ++ \\
\hline
\end{tabular}




\begin{tabular}{|c|c|c|c|c|}
\hline$\overline{39 .}$ & $\begin{array}{l}\text { Melilotus alba Medik ex Desr. } \\
\text { Oxalidaceae }\end{array}$ & - & $\mathrm{Fr}$ & ++ \\
\hline 40. & $\begin{array}{l}\text { Oxalis corniculata } \mathrm{L} \text {. } \\
\text { Pedaliaceae }\end{array}$ & Chariamilo & Veg & ++ \\
\hline 41. & $\begin{array}{l}\text { Sesamum indicum (Linn.) } \\
\text { Polygonaceae }\end{array}$ & Til & Veg & + \\
\hline 42. & Polygonum hydropiper $\mathrm{L}$. & Pirre & Veg & ++ \\
\hline 43. & P. plebeium $\mathrm{R}$. Br. & Sukul jhaar & Fr & ++++ \\
\hline 44. & $\begin{array}{l}\text { Rumex dentatus } \mathrm{L} . \\
\text { Primulaceae }\end{array}$ & Banpalungo & $\mathrm{Fr}$ & +++ \\
\hline 45. & $\begin{array}{l}\text { Anagallis arvensis } \mathrm{L} \text {. } \\
\text { Rubiaceae }\end{array}$ & Armale & $\mathrm{Fr}$ & ++++ \\
\hline 46. & $\begin{array}{l}\text { Hedyotis diffusa Wild } \\
\text { Scrophulariaceae }\end{array}$ & Majithe jhaar & $\mathrm{Fl}$ & ++ \\
\hline 47. & Mazus pumilus (Brum. f.) Van Steenis & Malati jhaar & $\mathrm{Fl}$ & ++ \\
\hline 48. & Mecardonia procumbens (Mill.)Small & - & Veg & ++ \\
\hline 49. & $\begin{array}{l}\text { Scoparia dulcis L. } \\
\text { Solanaceae }\end{array}$ & Baghejhaar & Veg & + \\
\hline 50. & Nicotiana plumbaginifolia Viv. & Bansurti & $\mathrm{Fl}$ & ++ \\
\hline 51. & $\begin{array}{l}\text { Solanum nigrum } \mathrm{L} \text {. } \\
\text { Verbenaceae }\end{array}$ & Jangalibihi & Fr & ++ \\
\hline 52. & $\begin{array}{l}\text { Lippia nodiflora (L.) Rich. } \\
\text { Monocotyledonae } \\
\text { Commelinaceae }\end{array}$ & Kurkure jhaar & $\mathrm{Fl}$ & ++ \\
\hline 53. & $\begin{array}{l}\text { Commelina benghalensis L. } \\
\text { Cyperaceae }\end{array}$ & Kanejhaar & Veg & + \\
\hline 54. & Cyperus rotundus $\mathrm{L}$. & Mothe & Veg & ++ \\
\hline 55. & $\begin{array}{l}\text { Kyllinga brevifolia Rottb. } \\
\text { Poaceae }\end{array}$ & Mothe & $\mathrm{Fl}$ & +++ \\
\hline 56. & Axonopus compressus (Sw.) P. Beauv. & - & Veg & + \\
\hline 57. & Brachiaria ramosa (L.) Stapf & - & Veg & + \\
\hline 58. & Cynodon dactylon (L.) Pers & Dubo & $\mathrm{Fl}$ & +++ \\
\hline 59. & Digitaria setigera Roth ex R. and S. & - & Veg & ++ \\
\hline 60. & Hemarthria compressa (L. f.) R. Br. & Ghode dubo & Veg & ++ \\
\hline 61. & Lolium temulentum $\mathrm{L}$. & Ghodejai & Fr & + \\
\hline 62. & Oryza sativa $\mathrm{L}$. & Dhan & Veg & + \\
\hline 63. & Paspalum distichum $\mathrm{L}$. & Banso & Seed & ++ \\
\hline 64. & Phalaris minor var. nepalensis (Trin.) Bor & Ragate jhaar & $\mathrm{Fr}$ & ++ \\
\hline 65. & Polypogon monspeliensis (L.) Desf & - & Veg & ++ \\
\hline 66. & Setaria pumila (Poiret.) & Ghogebanso & Seed & ++ \\
\hline 67. & Setaria sp. & Ghogebanso & Seed & ++ \\
\hline 68. & Sorghum halpense (L.) Pers & - & Seed & ++ \\
\hline
\end{tabular}

ature of the plant is based on Hara et al. (1978-1982). Hebarium specimens have been deposited in the T.U. Herbarium, Department of Botany, Post Graduate Campus, Tribhuvan University, Biratnagar, Nepal. When a phenophase was noticed in about $10 \%$ samples under observation the phenophase was considered to be initiated and to be in peak when it occurred in more than $80 \%$ individuals (Lodhiyal et al., 1998). Occurrence of weed was recorded visually as ++++ (abundant), +++ (frequent), ++ (occasional) and + (scarce) . 


\section{Results and discussion}

Sixty eight weed species belonging to 22 families and 59 genera were collected and identified (Tab. 1). Dicots dominated the weed flora (52 species, 44 genera and 19 families). Based on species prevalence the dominant families were in the order: Asteraceae (17 species) > Poaceae (13 species $)>$ Fabaceae (6 species) $>$ Amaranthaceae (4 species) $>$ Polygonaceae,

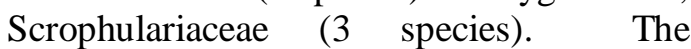
dominance of these families in the wheat field agrees with the earlier reports (Manandhar, 1978; Dangol, 1987; 20002002; Regmi et al., 1986). Anagallis arvensis, Grangea maderaspatana and Polygonum plebeium were abundant weeds. Frequent weeds in the wheat field were Alternanthera sessilis, Crepis japonica, Cynodon dactylon, Croton bonplandianm, Gnaphalium polycaulon, Fumaria indica, Kyllinga brevifolia Leucas lavandulifilia, Vicia angustifolia and V. hirsuta (Tab. 1).

Abundant (A. arvensis, C. japonica, $G$. polycaulon P. plebeium) and frequent weed species ( $F$. indica, Leucas lavandulifilia, Rumex dentatus, Vicia angustifolia, $V$. hirsuta and V. tetrasperma), were recorded in fruiting and seed stage, respectively. Cynodon dactylon and Kyllinga brevifolia in flowering form were also frequent. In general, weeds recorded in the vegetative phase were occasional and scarce in the preharvest wheat field. Dangol (2001) reported top 5 major species (Anagallis arvensis, Chenopodium album, Digittaria sanguinalis, Oxalis corniculata and Polygonum plebeium) of wheat from Rampur, Chitwan. In terms of dry biomass Anagallis arvensis, Cynodon dactylon, Grangea maderaspatana, Rumex dentatus and Vicia angustifolia are the major weeds in the wheat fields at Biratnagar (Niroula et al., 2006). Ability of enormous seed production, variety of seed dormancies, ability to grow and multiply in stressed conditions are the features of their ecological successes (Sen, 2000). A weed of minor status in one region/country may have the potential to become a major or serious pest in a new environment (Yaduraju et al., 2000).

Table 2. Weed families with number of genera and species.

\begin{tabular}{lcc}
\hline Family & Genus & Species \\
\hline Dicots & 2 & 2 \\
Acanthaceae & 2 & 4 \\
Amaranthaceae & 2 & 2 \\
Apiaceae & 16 & 17 \\
Asteraceae & 1 & 1 \\
Boraginaceae & 1 & 2 \\
Chenopodiaceae & 1 & 1 \\
Euphorbiaceae & 3 & 6 \\
Fabaceae & 1 & 1 \\
Fumaricaceae & 2 & 2 \\
Lamiaceae & 1 & 1 \\
Meliaceae & 1 & 1 \\
Pedaliaceae & 1 & 1 \\
Oxalidaceae & 2 & 3 \\
Polygonaceae & 1 & 1 \\
Primulaceae & 1 & 1 \\
Rubiaceae & 3 & 3 \\
Scrophulariaceae & 2 & 2 \\
Solanaceae & 1 & 1 \\
Verbenaceae & 12 & \\
\hline Monocots & 59 & \\
Commelinaceae & & 1 \\
Cyperaceae & & \\
Poaceae & 1 & \\
\hline Total & 12 & \\
\hline & & \\
\hline
\end{tabular}

\section{Acknowledgement}

I'm thankful to Professor and Head, Sasinath Jha Department of Botany, Post Graduate Campus, T.U., Biratnagar, Nepal for encouragements and laboratory facilities. 


\section{References}

Bhowmik, P.C. 2000. Future of weed science research in relation to food production and environment. In: Environment and Agriculture: At the crossroad of new millennium (Eds. P.K. Jha, S.B. Karmacharya, S.R. Baral and P. Lacoul). Ecological Society (ECOS), Nepal. pp.95-103.

Chaudhary, R.P. 1979. Reports on the weeds of Kathmandu valley. J. Nat. Hist. Mus. (Nepal) 3: 83-93.

Dangol, D.R. 1987. Survey of weeds in wheat field at Birgunj, Parsa, Nepal. J. Inst. Agric. Anim. Sci. 8: 45-51.

Dangol, D.R. 2000-2002. A comparison of weed flora of wheat fields of inner Terai and Terai of Nepal. J. Inst. Agric. Anim. Sci. 21-22: 95-103.

Dangol, D.R. 2001. Ecological studies and uses of winter crop at Rampur, Chitwan. In: Environment and Agriculture: Biodiversity, agriculture and pollution in South Asia (Eds. P.K. Jha, S.R. Baral, S.B. Karmacharya, H.D. Lekhak and C.B. Baniya). Ecological Society (ECOS), Nepal. pp. 430-434.

Devkota, R.N. 1983. Weeds of wheat field and their control (Nepali). Krishi 20: 20-24.

Hara, H. and L.H. Williams 1979. An enumeration of the flowering plans of Nepal Vol. 2, British Museum (Nat. Hist.), London.

Hara, H., A.O. Chater and L.H. Williams 1982. An enumeration of the flowering plants of Nepal Vol. 3, British Museum (Nat. Hist.), London.

Hooker, J.D. 1872-1897. The flora of British India, Vols. 1-7, L. Reeve, London.

Lodhiyal, L.S., S.P. Singh and N. Lodhiyal 1998. Phenology, population structure and dynamics of ringal bamboo (Arundinaria falcata) in Nainital hill of Central Himalaya. Tropical Ecology 39(1): 109-115.

Manandhar, N.P. 1978. A study of weds of the river banks of Kathmandu Valley. Bull. Bot. Surv. India 20(1-4): 36-47.

Niroula, B, R.K. Rai and M.K. Shrestha 2006. Phytosociology of wheat field weeds at Biratnagar, eastern Nepal. In: Natural Resource Management (Eds. S.B. Karmacharya, M.R. Dhakal, S.N. Jha, T.N. Mandal, M.K. Chettri, B.R. Subba, U. Koirala, B. Niroula and K.P. Limbu). P.G. Campus Biratnagar, Nepal Biological Society, Biratnagar and Ecological Society Kathmandu, Nepal. pp. 405-410.

Rajbhandari, K.R. and R. Joshi 1998. Crop weeds of Nepal. Natural History Society of Nepal, Kathmandu, Nepal.

Rajbhandary, K.L. and S. Ojha 1979. Notes on weeds associated with wheat crop. Nep. J. Agric. 14 (1314): 49-51.

Ranjit, J.D. 1983. Weed control trial on wheat. HMG, Department of Agriculture, NWDP, Siddarthanagar, Bhairhawa, Nepal. pp. 365-577.

Sen, D.N. 2000. Weeds in rainfed cropping in Indian desert. In: Environment and Agriculture : At the crossroad of new millennium (Eds. P.K. Jha , S.B. Karmacharya, S.R. Baral and P. Lacoul). Ecological Society (ECOS), Nepal. pp.95-103.

Yaduraju, N.T., P.C. Bhowmik and S. Kushwaha 2000. The potential threat of alien weeds to agriculture and environment. In: Environment and Agriculture: At the crossroad of new millennium (Eds. P.K. Jha, S.B. Karmacharya, S.R. Baral and P. Lacoul). Ecological Society (ECOS), Nepal. pp. 229-234. 